\title{
ANALISANDO A PERCEPCÃO DOS AGRICULTORES DE TRÊS MUNICÍPIOS DA REGIÃO NOROESTE DO RIO GRANDE DO SUL SOBRE A OFERTA DE PRODUTOS E SERVIÇOS AGRÍCOLAS
}

\author{
Cristina Kunkel ${ }^{1}$ \\ Monica Andrioli ${ }^{2}$ \\ Monize Sâmara Visentini ${ }^{3}$
}

\begin{abstract}
RESUMO
Este trabalho visa identificar, em municípios na região de Santa Rosa-RS, como os agricultores percebem a estrutura comercial no setor de máquinas e implementos agrícolas, que os atende e fornece subsídios para o desenvolvimento de suas atividades. Para tanto, elaborou-se um estudo descritivo e quantitativo, utilizando o método survey para a coleta dos dados com 65 agricultores dos municípios de Alecrim, Cândido Godói e Santo Cristo. Dentre os resultados da pesquisa, identificou-se que a maioria dos respondentes prefere realizar a manutenção do seu maquinário em suas propriedades ao invés de concessionárias. Os agricultores de Cândido Godói e de Santo Cristo utilizam mais os serviços oferecidos por empresas do município em que residem do que os agricultores de Alecrim. Com relação aos motivos que levam esses agricultores a escolher um estabelecimento comercial, tem-se destaque para a qualidade dos produtos e do atendimento oferecidos. Esses resultados são interessantes para empresas da região, a fim de melhorar sua oferta de produtos e serviços, bem como buscar maior competitividade. Também são relevantes para futuros empreendedores, que tenham interesse de atuação neste ramo.
\end{abstract}

Palavras-chave: máquinas agrícolas, implementos agrícolas, agricultores.

\section{ANALYZING FARMERS PERCEPTION OF THREE MUNICIPALITIES OF NORTHWEST OF RIO GRANDE DO SUL ABOUT THE AGRICULTURAL PRODUCTS AND SERVICES OFFERED}

\begin{abstract}
The following study aims to identify, at cities of Santa Rosa's region, how farmers perceived the commercial structure of agricultural machinery and implements sector, which advise and provide them with subsidies to development their activities. To this end, a descriptive and quantitative research was elaborated, using survey method to collect data among 65 farmers from the cities of Alecrim, Cândido Godói and Santo

\footnotetext{
${ }^{1}$ Graduanda em Administração (UFFS - Campus Cerro Largo). E-mail: cristinakunkel@hotmail.com ${ }^{2}$ Graduanda em Administração (UFFS - Campus Cerro Largo). E-mail: andrioli.monica@gmail.com

${ }^{3}$ Graduada em Administração (UFSM). Mestre em Administração (PPGA-UFSM). Doutora em Administração (PPGA-UFRGS). Professora Adjunta do Curso de Administração (UFFS - Campus Cerro Largo). E-mail: monize.visentini@uffs.edu.br
} 
Cristo. The results of the research indicate that most of the farmers prefer to do the machinery maintenance on their own property instead of taking the machinery to concessionaires. Although, farmers from Cândido Godói and Santo Cristo are more susceptible to use the services provided by their cities companies, than farmers from Alecrim. Regarding the leading reasons to choose a commercial establishment, quality of products and service offered were highlighted. Results present importance for agricultural companies of Santa Rosa's region, for it allows improvement of products and services offers, as well as the competitiveness. They are also relevant to future entrepreneurs interested in this line of work.

Keywords: agricultural machinery, agricultural implements, farmers.

\section{INTRODUÇÃO}

Vian e Andrade Júnior (2010), contextualizando as técnicas de produção agrícola, destacam que, nos primórdios, as mesmas eram rudimentares e manuais, mas com o passar dos anos foram se aperfeiçoando, através do desenvolvimento de alguns equipamentos agrícolas, puxados por animais, até chegar aos equipamentos utilizados atualmente. Essas mudanças se fizeram necessárias para suprir a demanda de alimentos, pois há cada vez menos pessoas no campo e, consequentemente, menos mão de obra. Com a evolução paralela da tecnologia e da indústria, percebeu-se o aprimoramento nas técnicas de produção agrícola. Com a criação de máquinas e equipamentos agrícolas, houve um grande aperfeiçoamento nas técnicas produtivas, diminuindo a mão de obra e o tempo gasto na produção agrícola (VIAN; ANDRADE JÚNIOR, 2010).

Segundo Vian et al. (2013), com a evolução do setor de máquinas e implementos agrícolas, foi crescente a oferta ao mercado destes equipamentos de tecnologia avançada, o que contribuiu para o aumento da produtividade no meio rural. Quando se analisa o cenário brasileiro, o setor de máquinas e implementos agrícolas apresenta relevância, especialmente, quando se trata do aumento na geração de empregos e arrecadação de impostos (OLIVEIRA, 2008). Especificamente, no Estado do Rio Grande do Sul (RS), este setor é um "importante fornecedor de bens de capital para o agronegócio gaúcho e brasileiro", justificando a importância de estudá-lo (PASCOAL; PEDROSO, 2007, p. 4).

Outro fator relevante relacionado a este setor é que, com a utilização das máquinas e implementos agrícolas, é possível que se tenha mais de uma safra por ano. "O setor de máquinas atravessa uma fase de transformação da agropecuária brasileira, que tende a demandar cada vez mais equipamentos maiores, com nível mais elevado de tecnologia, dado o crescimento da agricultura de precisão, e capazes de proporcionar um melhor aproveitamento da segunda safra" (FERO, 2014, p. 2).

A evolução do meio rural também ocorreu na região noroeste do estado do $\mathrm{RS}$, caracterizada pela produção agrícola voltada, principalmente, para o plantio de soja, milho, trigo e produção leiteira. Conforme pesquisa desenvolvida por Mallmann e Lago (2012), com agricultores de um município dessa região, a vida dos agricultores antes de possuírem máquinas e implementos agrícolas era cansativa, e exigia esforço físico; entretanto, atualmente, a vida no campo é justamente o oposto. Neste sentido, Stefanoski et al. (2013) salientam que além das tecnologias embutidas nos maquinários e implementos agrícolas, os agricultores também dão preferência por sementes selecionadas e certificadas; buscando garantir, assim, que se houver condições climáticas adequadas, haverá germinação e produtividade. 
Segundo Castilhos (2007), é nesta região do estado do RS que está concentrada a produção de máquinas e equipamentos agrícolas, sendo esta aglomeração percebida a partir da década de 1970. Essa autora destaca que a diversidade de produção industrial da região revela a presença de três grupamentos: o de máquinas agrícolas (colheitadeiras, semeadoras, pulverizadoras, secadoras e outras) e de tratores; o dos fornecedores de peças e componentes; e o de produtores de implementos agrícolas (ferramentas e equipamentos manuais ou tracionados). Além de relevância industrial para o setor agrícola, a região noroeste também representa um polo na cultura de grãos. De acordo com indicadores da EMATER (2014), no município de Santa Rosa, localizado na região noroeste do estado do RS, são cultivados mais de 660 mil hectares de soja, 159 mil hectares de milho e aproximadamente 3,5 mil hectares de trigo.

Tendo em vista o impacto econômico gerado por este setor, acredita-se ser relevante investigar como os agricultores atuantes nos municípios da região noroeste percebem a oferta de serviços e produtos agrícolas, como máquinas, implementos e peças. Para tanto, delineou-se um corte nesta investigação, estudando a percepção de agricultores de três municípios da região da Grande Santa Rosa sobre estrutura comercial no setor de máquinas e implementos agrícolas. Esses municípios são: Alecrim, Santo Cristo e Cândido Godói, que possuem uma porcentagem alta da população residente no meio rural em relação à porcentagem do Rio Grande do Sul e do Brasil. Para que as empresas deste setor sejam competitivas no mercado, é necessário que visem à inovação constante, através da utilização de tecnologia de ponta, assim como a busca do contato com o cliente final para saber o que este realmente precisa, desenvolvendo produtos para atender as suas necessidades (OLIVEIRA, 2008).

A partir desta discussão, o problema de pesquisa deste estudo define-se como: "De que forma os agricultores de Santo Cristo, Alecrim e Cândido Godói percebem a oferta de máquinas, implementos, peças e serviços agrícolas nos seus municípios e região?". A partir deste questionamento norteador, este estudo visa identificar como os agricultores dos municípios pesquisados, localizados na região de Santa Rosa - RS, percebem a estrutura comercial no setor de máquinas e implementos agrícolas, que os atende e fornece subsídios para o desenvolvimento de suas atividades.

A população rural do Brasil é de $15,6 \%$, no Rio Grande do Sul este índice é de 14,9\% (Instituto Brasileiro de Geografia e Estatística, IBGE, 2010). Já nas cidades pesquisadas a de menor índice foi Santo Cristo $(45,9 \%)$, seguida pela cidade de Alecrim (69,3\%). Por outro lado, Cândido Godói possui $71,8 \%$ de sua população residente no meio rural. Tendo em vista à população que reside no meio rural desses municípios, este estudo justifica-se por compreender a percepção dos agricultores quanto ao suporte que recebem das empresas dos respectivos municípios para o desenvolvimento das suas atividades agrícolas.

Além disso, acredita-se que os resultados deste estudo irão possibilitar aos empresários do setor de máquinas e implementos agrícolas dos três municípios pesquisados um panorama acerca das principais necessidades destes agricultores. Tais resultados tornam-se relevantes, na medida em que as empresas do ramo de máquinas agrícolas, para serem competitivas, devem realizar pesquisa de mercado e de tendências de consumo, se antecipar às mudanças de mercado, contando com pessoas que possuam conhecimento do que fazem, bem como possibilitem assessoria técnica qualificada (OLIVEIRA, 2008).

No que tange à discussão acadêmica acerca desta temática, Mallmann e Lago (2012) descrevem as mudanças ocorridas com a introdução das novas tecnologias no meio rural que são relatadas pelos agricultores do município de Cerro 
Largo (RS). Já Castilhos et al. (2008), enfatizam as indústrias que produzem máquinas e equipamentos agrícolas situadas no Rio Grande do Sul, dando prioridade à história das empresas com suas respectivas fusões e aquisições. Em contrapartida, Oliveira (2008) discute a importância do marketing no prédesenvolvimento de máquinas agrícolas, para que estes produtos tenham um diferencial competitivo e também satisfaçam as necessidades dos clientes. Indo ao encontro destes estudos, de ampliar e qualificar a discussão acadêmica acerca deste setor econômico, esta pesquisa visa contribuir na ampliação do conhecimento acerca das características e necessidades dos agricultores da região estudada.

\section{REVISÃO DE LITERATURA}

Neste capítulo é apresentada a fundamentação teórica que dará suporte para a pesquisa, sendo discutida a evolução da indústria de máquinas agrícolas no Brasil, bem como as principais máquinas utilizadas atualmente neste setor.

\subsection{Evolução da indústria de máquinas agrícolas no Brasil}

O homem não nasceu agricultor, em sua origem, sabia apenas caçar e coletar frutos, mas com sua evolução começou a desenvolver técnicas e instrumentos para cultivar a terra, que foram aperfeiçoadas de acordo com suas necessidades (MAZOYER; ROUDART, 2001). Até o século XVIII os instrumentos utilizados pelos agricultores eram rudimentares e feitos artesanalmente. Porém, com a crescente demanda de alimentos, essas técnicas foram aperfeiçoadas para que a demanda fosse atendida (VIAN et al., 2013).

No cenário nacional, foi durante o Governo de Juscelino Kubitschek, nos anos 50, que a indústria ganhou impulso, em consequência do "Plano de Metas", que visava compensar o atraso da economia brasileira em relação aos outros países industrializados (AMATO NETO, 1985). Juntamente com a implementação da indústria automobilística surge a indústria de máquinas agrícolas, que inicia sua produção no ano de 1960. Até então havia uma grande dependência em relação à importação destes produtos (AMATO NETO, 1985). Para ilustrar esta situação, a Tabela 1 apresenta dados das vendas nacionais e da produção de tratores sobre rodas e de colhedoras no país, no período entre 1960 e 2014. 
Tabela 1 - Venda e produção de tratores e colhedoras de 1960 à 2014.

\begin{tabular}{ccc|cc}
\hline \multirow{2}{*}{ Período } & \multicolumn{2}{c}{ Tratores de rodas } & \multicolumn{2}{c}{ Colheitadeiras de grãos } \\
\cline { 2 - 5 } & $\begin{array}{c}\text { Vendas } \\
\text { nacionais }\end{array}$ & Produção & $\begin{array}{c}\text { Vendas } \\
\text { nacionais }\end{array}$ & Produção \\
\hline 1960 & 37 & 37 & 0 & 0 \\
1965 & 8.401 & 8.401 & 0 & 0 \\
1970 & 14.586 & 14.326 & 0 & 0 \\
1975 & 57.101 & 58.301 & 0 & 0 \\
1980 & 50.195 & 57.974 & 5.410 & 6.003 \\
1985 & 40.736 & 43.398 & 5.775 & 6.427 \\
1990 & 21.241 & 24.223 & 2.350 & 2.971 \\
1995 & 17.584 & 21.044 & 1.423 & 2.371 \\
2000 & 24.291 & 27.546 & 3.628 & 4.296 \\
2005 & 17.543 & 40.871 & 1.533 & 4.229 \\
2010 & 55.707 & 71.763 & 4.507 & 7.007 \\
2014 & 55.230 & 64.783 & 6.433 & 7.623 \\
\hline
\end{tabular}

Fonte: ANFAVEA (2015)

A produção teve evolução constante até meados de 1980. Após estes episódios de crescimento, a produção e as vendas tiveram uma redução. Amato Neto (1985, p. 4) destaca que "a partir de 1979 aconteceram profundas alterações no sistema de crédito rural para investimentos, redundando em crescentes e contínuos cortes nos volumes de venda do setor, situação esta que persiste no ano de 1985". Os anos seguintes possuem variações na produção e vendas. A grande maioria da produção nacional foi destinada à venda nacional e apenas uma pequena parte foi destinada à exportação.

A partir do ano de 2000, as vendas de tratores de rodas e colheitadeiras de grãos aumentaram. De acordo com Felipe, Lima e Rodrigues (2009), uma das consequências para esse aumento foi criação do Programa de Modernização da Frota de Tratores Agrícolas e Implementos Associados e Colheitadeiras (MODERFROTA). O Programa MODERFROTA teve início no ano de 2000 , sendo responsável pelo aumento da demanda por máquinas agrícolas, ocasionando o crescimento de consumo em unidades, excetuando-se o ano de 2005, no qual houve baixa rentabilidade das culturas. Através desse Programa foi possível renovar mais um terço da frota de maquinários agrícolas do País, maquinários esses com mais tecnologia (FELIPE; LIMA; RODRIGUES, 2009). Esses autores ainda discorrem que o aumento das vendas, no período dos anos 2000, também foi ocasionado pela melhoria da renda agrícola, pois, nesse período, os preços dos produtos agrícolas estavam elevados. Com a utilização de maquinários com maior tecnologia e potência é possível aumentar a oferta de alimentos com um custo competitivo, pois os serviços são executados em menor tempo e com custos mais baixos (VEGRO; FERREIRA, 2008). 


\title{
2.2 Principais máquinas utilizadas atualmente
}

Para gerar vantagem competitiva às empresas do ramo agrícola é necessário conhecer quem são os agricultores, que tipos de máquinas e implementos agrícolas possuem e suas necessidades (MAZOYER; ROUDART, 2001). Agricultores são as pessoas que trabalham no campo, utilizando-se das técnicas de plantio, tratamento, colheita e venda de alimentos/grãos. As ferramentas utilizadas no campo e analisadas nesta pesquisa são as peças, máquinas e implementos agrícolas, bem como as respectivas assistências técnicas.

Neste estudo, considera-se peça como uma parte de um implemento ou máquina agrícola. Conforme Silveira (1989), se pode encontrar vários tipos de máquinas que ajudam o homem no campo, facilitando o seu trabalho e reduzindo ao máximo o esforço do agricultor. Sabe-se que uma das máquinas mais utilizadas no meio rural é o trator, que transfere energia para os mais variados implementos agrícolas, fazendo-os funcionar. Implemento agrícola é um acessório mecânico que acoplado a um trator realiza movimentos próprios ou induzidos para realização de sua função (SANTOS FILHO; SANTOS, 2001). Reis et al. (2005) observaram uma tendência de aumento de vendas de tratores maiores, de maior potência e maior número de funções, pois o espaço de cultivo do solo aumentou.

Para fazer o plantio mecanizado, utiliza-se uma plantadora/semeadora, que tem uma grande importância, já que a colheita depende de uma boa semeadura (SILVEIRA, 1989). Conforme Machado (2005 apud ABNT 1996, p. 107).

\begin{abstract}
A semeadora é a máquina agrícola que realiza a operação de semeadura de espécies vegetais, cuja reprodução é feira por meio de sementes. Suas principais funções são dosar as sementes, abrir o sulco de semeadura, depositar as sementes no fundo do sulco e cobri-las com uma camada de terra.
\end{abstract}

Para fazer o tratamento das plantas contra doenças e insetos é utilizado o pulverizador, um implemento que tem a função de distribuir igualmente gotículas de defensivo sobre as superfícies a serem tratadas. No manuseio do pulverizador, é necessária a proteção individual, incluindo luvas, roupas adequadas, máscaras e botas para evitar o contato direto com o defensivo, que é prejudicial à saúde (SILVEIRA, 1989).

Após o preparo do solo, semeadura e tratamento, realiza-se a colheita. Nesta etapa usa-se a colhedora, a qual são atribuídos os "esforços de colheita, limpeza e armazenamento dos grãos juntos ao tanque graneleiro para posterior descarga em locais de armazenamento secundário apropriado" (PEDÓ; ESTEVES, 2013 p. 15).

A manutenção e conservação de maquinários são práticas de revisão e restauração, para recuperar ou preservar a capacidade funcional dos equipamentos (DANTAS, 2010). Conforme este autor, a manutenção é dividida em três categorias: manutenção preventiva, feita para prevenir; manutenção preditiva, na qual calcula-se o tempo de duração de uma peça, por exemplo, e depois faz-se a manutenção preventiva; e a manutenção de rotina, efetuada diariamente. Reis et al. (2005) complementam que precisa ser realizada a manutenção periódica, pois os motores podem ser danificados pelas impurezas, temperatura e desgaste. Essa manutenção deve ser criteriosa, seguindo as indicações do fabricante (SILVEIRA, 1989).

Sabe-se que após vários anos de uso do solo, é preciso repor seus nutrientes, através do distribuidor de fertilizante. De acordo com Silveira (1989), este é acoplado a um trator, o qual transfere potência, fazendo com que ele funcione. Há 
vários tipos de distribuidor de fertilizante, sendo mais utilizado no Brasil o distribuidor com disco rotativo.

Já no que diz respeito ao preparo e armazenamento de forragens (plantas e grãos para alimentação animal), os agricultores utilizam a ensiladora, implemento que tritura e lança as forragens para as carretas, para posteriormente ser levado para o silo ou diretamente no local de alimentação dos animais (FERREIRA et al., 2003). Esses autores ainda destacam que as ensiladoras são bastante utilizadas em pequenas propriedades rurais devido ao baixo custo de aquisição, operação e manutenção, e que estas são acopladas a um motor elétrico, através de um micro trator ou trator.

Já a enfardadora "é a máquina que coleta o feno em leiras e o comprime, tornando-o mais denso, formando os fardos" (ALONÇO; MACHADO; FERREIRA, $p$. 161, 2007). O manuseio desta máquina é fácil, sendo acoplada a um trator, necessitando de pouca mão de obra; o armazenamento dos fardos é prático e possui baixo investimento.

Essas máquinas e implementos são apenas alguns dos instrumentos que os agricultores podem possuir em sua propriedade para facilitar seus serviços, e são importantes de serem discutidas nesta seção para nortear a análise dos resultados desta pesquisa.

\section{METODOLOGIA}

Esta pesquisa classifica-se como descritiva, que, segundo Cooper e Schindler (2011), visa à descrição de fatos ou atributos da amostra da pesquisa. A abordagem usada é quantitativa, que possibilita analisar um número grande de amostra, focando em descrever, explicar e prever (COOPER; SCHINDLER, 2011). Como método de coleta de dados utilizou-se o levantamento (ou survey), que consiste na coleta de dados em forma de um questionário estruturado com perguntas padronizadas e com ordem predeterminada para todos os respondentes (MALHOTRA, 2012). O questionário foi baseado no trabalho de Kirchner et al. (2012), que aplicaram a metodologia SERVPERF, a fim de avaliar, na óptica do cliente, a qualidade dos serviços oferecidos por uma empresa do ramo agrícola na região das Missões (RS).

O questionário foi submetido ao processo de validação de conteúdo, que, conforme Hair Junior et al. (2007), envolve a consulta a uma pequena amostra de respondentes, geralmente especialistas no assunto a ser tratado, para julgar a adequação dos itens escolhidos para representar o tema abordado. Assim, solicitouse a avaliação de dois professores do Curso de Agronomia e três do Curso de Administração de uma Universidade Federal, situada no interior do RS. Esses especialistas realizaram comentários e sugestões de melhorias para o aperfeiçoamento de algumas questões. Os ajustes sugeridos foram implantados, a fim de melhor adequar o instrumento à amostra investigada.

A aplicação do questionário foi realizada através de um instrumento auto preenchido, o qual, de acordo com Mattar (2005), os próprios pesquisados leem e preenchem sem intervenção do entrevistador, sendo os questionários levados até a residência dos pesquisados. O período de aplicação compreendeu de 29 de novembro de 2013 a 03 de janeiro de 2014, alternando o município.

Quanto aos procedimentos de amostragem, utilizou-se a amostragem não probabilística por conveniência, que permite ao pesquisador escolher sua população amostral (AAKER; KUMAR; DAY, 2011). A amostragem por conveniência é uma forma rápida e barata de obter informações, dando liberdade para o pesquisador coletar grupos de amostras convenientes (AAKER; KUMAR; DAY, 2011). Em 
decorrência dos recursos para a realização da pesquisa e da impossibilidade de deslocamento pela zona rural de todos os municípios pertencentes à região da grande Santa Rosa, foi necessário realizar um corte na amostra, sendo selecionados alguns dos municípios com maior densidade de agricultores da região investigada.

Assim, foram selecionados os agricultores dos municípios de Alecrim, Cândido Godói e Santo Cristo, que possuíam propriedades rurais de pequeno e médio porte, para que houvesse uma maior amplitude de respostas. De acordo com Pontual (2011), é considerada pequena propriedade rural com até 30 hectares, dependendo de sua localização. Nesse sentido, Alcantara Filho e Fontes (2009) afirmam que há variações entre regiões, pelo fato de que a produtividade da terra em algumas regiões do país ser diferente de outras, ou seja, em alguns Estados do país é necessário que se tenha uma grande extensão de terra para que uma família possa sobreviver. Assim, neste estudo, propriedades com até 30 hectares foram consideradas de pequeno porte, as de médio porte são caracterizadas entre 30 e 50 hectares e as que possuíam mais de 50 hectares foram classificadas como de grande porte.

Todos os questionários foram aplicados ao proprietário da propriedade rural, sendo este o responsável pela manutenção de seus respectivos equipamentos e pela compra dos mesmos. Nos municípios de Alecrim e Cândido Godói foram aplicados 25 questionários em cada um e no município de Santo Cristo foram aplicados 15 questionários, totalizando 65 questionários válidos. A investigação de um número maior de agricultores foi limitada, pois muitos dos agricultores visitados não estavam disponíveis para responder ao estudo no momento da visita das pesquisadoras nas propriedades rurais.

Esses municípios situam-se no noroeste do estado do Rio Grande do Sul, especificamente na região da Grande Santa Rosa. O município de Alecrim, com base nos dados do IBGE (2010), possui $314.743 \mathrm{~km}^{2}$ e uma população de 7.045 habitantes, sendo quase $70 \%$ residentes do meio rural. Já o município de Cândido Godói possui área de $246.276 \mathrm{~km}^{2}$ e população 6.535 habitantes, $72 \%$ residindo na zona rural. O maior dentre os três municípios é Santo Cristo, que possui área de $366.886 \mathrm{Km}^{2}$ e 14.378 habitantes, sendo que quase $46 \%$ deles residem no meio rural. No Quadro 1 há a descrição das distâncias entre os municípios pesquisados e entre esses municípios e a cidade de Santa Rosa, a fim de situar o leitor na área de abrangência desta pesquisa.

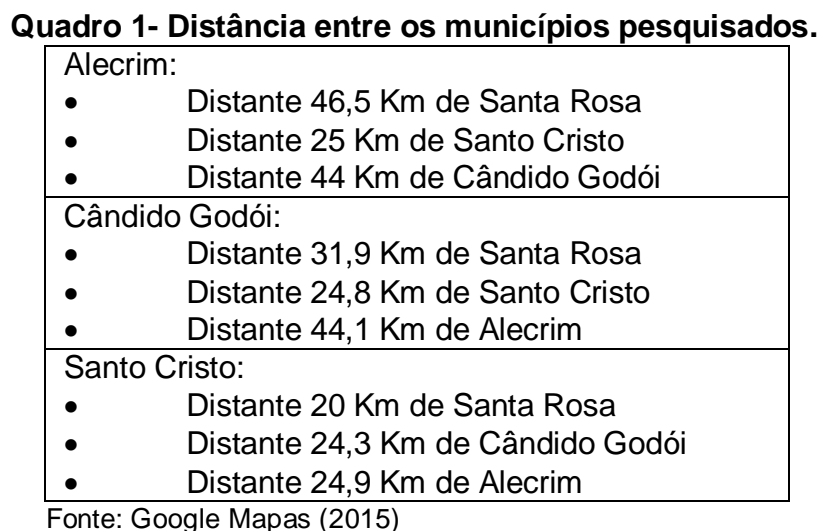


Como se pode perceber, a distância entre os municípios pesquisados não é grande. $\mathrm{O}$ acesso principal dos três municípios é por rodovia asfaltada e, alguns acessos secundários, são por estrada de chão.

Para a análise dos dados foram utilizadas técnicas de estatística descritiva e de testes de hipóteses através dos softwares "Microsoft Office Excel 2010 ${ }^{\text {TM" }}$ e "Statistical Package for the Social Sciences ${ }^{\mathrm{TM}}$ - SPSS 21.0".

\section{ANÁLISE DOS RESULTADOS}

Neste capítulo serão apresentados os resultados dos dados coletados. Foram aplicados 67 questionários, dos quais dois foram descartados com a finalidade de chegar mais próximo possível da realidade, pois nestes questionários havia questões relevantes que estavam incompletas. No Infográfico 1 são apresentados os dados referentes ao perfil dos agricultores pesquisados.

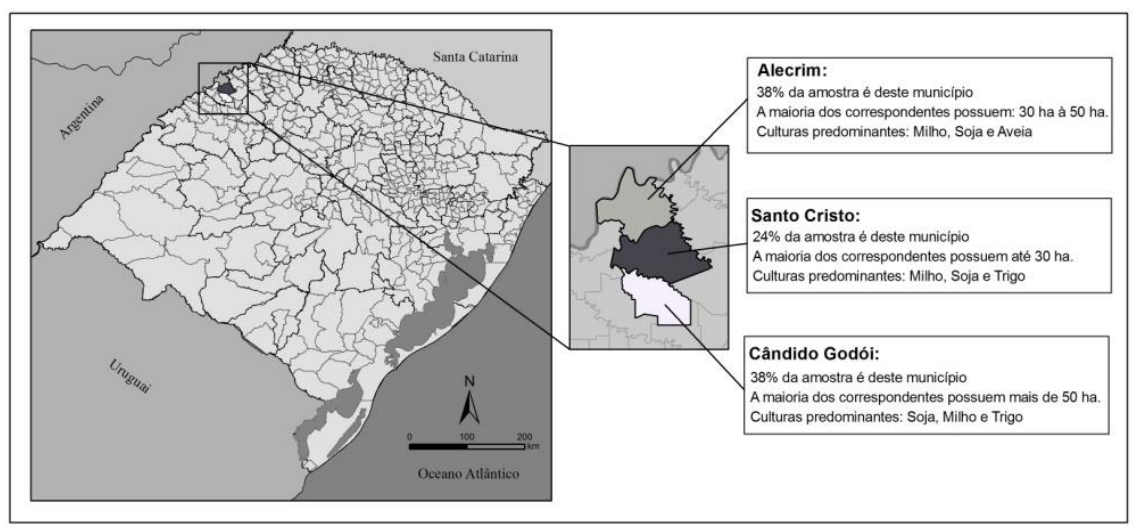

INFOGRÁFICO 1 - Perfil dos respondentes de cada município pesquisado Fonte: Elaborado pelas autoras

Considerando os 65 questionários válidos, obteve-se, em Alecrim e em Cândido Godói, 38\% de questionários respondidos e em Santo Cristo 24\% dos respondentes. No Infográfico 1 também é possível identificar o porte das propriedades da amostra. No município de Alecrim, as propriedades são, em sua maioria, de médio porte, sendo que $40 \%$ delas possuem entre 30 ha e 50 ha. Diferente de Cândido Godói que, das 25 propriedades pesquisadas, 46\% possuem mais de 50 há e do município de Santo Cristo, no qual, $47 \%$ das propriedades possuem até 30 ha.

Dentre as propriedades que compõem a amostra, várias possuem maiores extensões de terras, permitindo desse modo que possa ser cultivado mais de um tipo de cultura. A Tabela 2 apresenta as culturas predominantes em cada município estudado. 
Tabela 2 - Culturas predominantes em cada município.

\begin{tabular}{lcccc}
\hline \multicolumn{5}{c}{ Município } \\
\hline Cultura & Santo Cristo & Cândido Godói & Alecrim & Total \\
\hline Soja & $87 \%$ & $88 \%$ & $72 \%$ & $82 \%$ \\
Milho & $100 \%$ & $88 \%$ & $100 \%$ & $95 \%$ \\
Trigo & $67 \%$ & $84 \%$ & $32 \%$ & $60 \%$ \\
Aveia & $47 \%$ & $60 \%$ & $72 \%$ & $62 \%$ \\
Azevém & $47 \%$ & $48 \%$ & $56 \%$ & $51 \%$ \\
Outro & $7 \%$ & $24 \%$ & $16 \%$ & $17 \%$ \\
\hline Total de respondentes & 15 & 25 & 25 & 65 \\
$\%$ Total & $24 \%$ & $38 \%$ & $38 \%$ & $100 \%$ \\
\hline
\end{tabular}

Fonte: Elaborado pelas autoras

A maioria dos respondentes (95\%), independente do município, planta milho, $82 \%$ plantam soja, $62 \%$ plantam aveia (para alimentação do gado leiteiro) e $60 \%$ cultivam trigo. Este resultado vai ao encontro aos dados publicados pela EMATER (2014), de que as culturas mais plantadas são soja, milho e trigo na região da grande Santa Rosa. A alta incidência do cultivo do milho nesta região é também explicada pelo fato de que os produtores rurais produzem este cereal para subsidiar a produção de leite, aves e suínos (BRUM; LUFT, 2008). O estado do Rio Grande do Sul é o segundo maior produtor de leite (GRAEF; BÜTTENBENDER, 2014), sendo que na mesorregião noroeste (região em que estão situados os municípios pesquisados) está concentrada cerca de $66 \%$ da produção de leite do estado (GRAEF; BÜTTENBENDER, 2014; PUDELL, 2006). Nesta questão os respondentes podiam assinalar mais de uma alternativa, consequentemente, a soma das porcentagens é superior a cem por cento (100\%).

Sabe-se que, para o cultivo da terra, cada vez mais os maquinários e implementos agrícolas estão ganhando espaço, por proporcionarem ao operador maior agilidade, precisão e facilidade na hora do trabalho. A Tabela 3 apresenta as principais máquinas e implementos agrícolas utilizadas pelos agricultores investigados.

Tabela 3 - Análise dos principais maquinários e implementos agrícolas.

\begin{tabular}{lcc}
\hline Maquinário/Implemento & $\mathrm{n}^{\circ}$ de respondentes & $\%$ dos respondentes \\
\hline Trator & 65 & $100 \%$ \\
Colhedora & 30 & $46 \%$ \\
Distribuidor de Esterco & 15 & $23 \%$ \\
Roçadora & 24 & $37 \%$ \\
Ensiladora & 28 & $43 \%$ \\
Desensiladora & 2 & $3 \%$ \\
Pulverizador & 58 & $89 \%$ \\
Plantadora & 60 & $92 \%$ \\
Plataforma de milho & 12 & $18 \%$ \\
Distribuidor de fertilizante & 42 & $67 \%$ \\
Grade/Subsolador/Arado & 51 & $78 \%$ \\
Enfardadora & 1 & $2 \%$ \\
Outros & 13 & $20 \%$ \\
\hline
\end{tabular}

Fonte: Elaborada pelas autoras 
Dentre os respondentes, todos possuem tratores, sendo que alguns possuem mais de um. Esta alta incidência de tratores nas propriedades rurais é justificada pelo fato de esta ser uma máquina que produz potência, que pode ser transferida para implementos que funcionam exclusivamente se acoplados a ela. Quanto às colhedoras, apenas $46 \%$ dos respondentes as possuem. Uma possível explicação para este resultado é a proporção da amostra representada por pequenas propriedades. Isso porque, o custo de aquisição e manutenção é um fator que interfere na compra da colhedora e, por este motivo pode não ser viável tê-la em pequenas propriedades rurais, sendo mais rentável terceirizar o serviço de colheita. Conforme Bottega et al. (2015), o custo total de uma colhedora, considerando a aquisição da plataforma de soja e milho, varia entre $R \$ 431.500,00$ à $R \$ 830.500,00$, sendo esses dados obtidos pelos autores no ano de $2012 \mathrm{em}$ revendas autorizadas no estado do Paraná, e os preços variando em função de haver diferentes marcas, modelos, potências e sistemas de trilha.

Com base na Tabela 3, pode-se observar que aproximadamente $23 \%$ dos respondentes possuem distribuidor de esterco. Uma das possíveis justificativas para este baixo índice, segundo os pesquisados, é o fato de que alguns municípios dispõem este serviço mediante pagamento de uma taxa, sendo este um custo de manutenção a menos para os agricultores. Quanto às roçadoras, apenas $37 \%$ dos pesquisados as possuem, o que pode ser justificado pela disponibilidade de roçadoras manuais, que facilitam o manuseio e são mais econômicas e de custo baixo. Já a ensiladora está presente em $43 \%$ das propriedades. Este é mais útil para os agricultores que trabalham com gado leiteiro, para o preparo e o armazenamento de forragens. Quanto à desensiladora, por não ser prioridade de compra da amostra da pesquisa, foi encontrada em apenas duas das propriedades investigadas.

Sabe-se que dentre as formas de controlar pragas e insetos, tem-se a aplicação de agrotóxicos. Para obter a eficácia desses produtos, faz-se necessário a aplicação quando as condições climáticas são adequadas, sem perder tempo. Dessa maneira é relevante a utilização de um pulverizador, o que corrobora o achado de que $89 \%$ dos pesquisados o possuem. A plantadora também é um implemento necessário para os agricultores que cultivam grãos. Conforme a Tabela 3 , a maioria dos pesquisados (92\%) possuem este equipamento, sendo que alguns possuem duas, o que é facilmente justificado em virtude da extensão de terras de alguns entrevistados.

O distribuidor de fertilizante, que é importante para repor os nutrientes do solo, está presente em $67 \%$ das propriedades pesquisada. Já a enfardadeira foi detectada em apenas 1 propriedade (2\%). Este implemento é utilizado para fazer fardos de forragens específicas e a aquisição apresenta custos elevados. Assim, segundo os pesquisados, é mais viável terceirizar este serviço. Também foi identificada a utilização de outros implementos para o preparo do solo, como a grade, o subsolador e o arado, sendo que a maioria utiliza uma ou mais destas ferramentas. Implementos como esses proporcionam maior facilidade no cultivo no campo, entretanto, não garantem a produtividade, já que no meio rural há uma grande dependência de fatores climáticos para se obter uma boa safra (REDIN, 2011).

Segundo Pudell (2006 p. 60), o setor de máquinas e implementos agrícolas "possui grande dependência em relação ao comportamento da agricultura como um todo, isto devido à insuficiência de linhas de crédito destinadas ao crédito rural e também pelas oscilações dos preços dos produtos agrícolas". De acordo com o mesmo autor, esse setor, juntamente com os agricultores, pressionam o Governo Federal e Estadual para que liberem mais linhas de crédito para a atividade no meio rural. 
Com tantos maquinários e implementos agrícolas é preciso realizar manutenção dos mesmos para evitar possíveis imprevistos e danos maiores. Constatou-se que $97 \%$ os respondentes realizam manutenção periódica das ferramentas de trabalho que possuem. Esta manutenção é realizada em diferentes locais, como se observa no Gráfico 1.

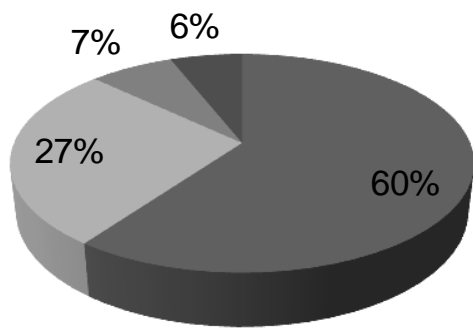

- Propriedade

- Oficina Mecânica

Concessionária

- Não responderam

\section{Gráfico 1- Locais em que os agricultores realizam a revisão das máquinas e implementos agrícolas.}

Fonte: Elaborado pelas autoras

Independente do município, $60 \%$ dos agricultores preferem realizar a manutenção em sua propriedade, uma das possíveis justificativas é a difícil locomoção das máquinas e implementos agrícolas dentro da cidade. Já $27 \%$ deles preferem realizar a revisão em uma oficina mecânica, porque lá encontram todas as peças que precisam, conforme comentários dos agricultores durante a pesquisa. Apenas uma minoria (7\%) realiza a manutenção em uma concessionária, principalmente porque as máquinas ainda estão em garantia. Este tipo de manutenção, realizada pelos agricultores, caracteriza-se por ser do tipo preventiva e de rotina (DANTAS, 2010).

$\mathrm{Na}$ Tabela 4, pode-se visualizar a cidade em que os agricultores realizam a manutenção de seus equipamentos. Nesta Tabela, o total das linhas é superior a $100 \%$ (cem por cento), pois era permitido assinalar mais de um município em que os entrevistados realizam a revisão. O município da revisão da máquina/implemento refere-se à cidade que possui uma assistência/revenda autorizada da marca ou a cidade em que o agricultor julga possuir a manutenção de acordo com suas preferências. Houve casos em que os agricultores possuíam dois tratores, por exemplo, e cada um era de uma marca diferente. Se um estava na garantia, é necessário leva-lo até a empresa que oferece este tipo de serviço, já o outro trator, que não está mais na garantia, pode ser levado ao local mais conveniente para o agricultor. 
Tabela 4 - Municípios em que os agricultores realizam a revisão Municípios em que realizam a revisão dos implementos/máquinas

\begin{tabular}{|c|c|c|c|c|c|c|c|c|}
\hline & & $\begin{array}{l}\text { Santo } \\
\text { Cristo }\end{array}$ & $\begin{array}{l}\text { Santa } \\
\text { Rosa }\end{array}$ & $\begin{array}{c}\text { Porto } \\
\text { Lucena }\end{array}$ & Alecrim & $\begin{array}{c}\text { Cândido } \\
\text { Godói }\end{array}$ & Outro & Total \\
\hline \multirow{3}{*}{$\begin{array}{c}\mathrm{M} \\
\mathrm{U} \\
\mathrm{N} \\
\mathrm{I} \\
\mathrm{C} \\
\mathrm{I} \\
\mathrm{P} \\
\mathrm{I} \\
\mathrm{O}\end{array}$} & $\begin{array}{l}\text { Santo } \\
\text { Cristo }\end{array}$ & $\begin{array}{c}12 \\
(86 \%)\end{array}$ & $\begin{array}{c}4 \\
(29 \%)\end{array}$ & 0 & 0 & 0 & 0 & 14 \\
\hline & $\begin{array}{c}\text { Cândido } \\
\text { Godói }\end{array}$ & 0 & 0 & 0 & 0 & $\begin{array}{c}24 \\
(100 \%)\end{array}$ & 0 & 24 \\
\hline & Alecrim & $\begin{array}{c}5 \\
(20 \%)\end{array}$ & $\begin{array}{c}10 \\
(40 \%)\end{array}$ & $\begin{array}{c}1 \\
(4 \%)\end{array}$ & $\begin{array}{c}15 \\
(60 \%)\end{array}$ & 0 & $\begin{array}{c}2 \\
(8 \%)\end{array}$ & 25 \\
\hline & Total & $\begin{array}{c}17 \\
(27 \%)\end{array}$ & $\begin{array}{c}14 \\
(22,2 \%)\end{array}$ & $\begin{array}{c}1 \\
(1,6 \%)\end{array}$ & $\begin{array}{c}15 \\
(23,8 \%)\end{array}$ & $\begin{array}{c}24 \\
(38,1 \%)\end{array}$ & $\begin{array}{c}2 \\
(3,2 \%)\end{array}$ & $\begin{array}{c}63^{*} \\
(100 \%)\end{array}$ \\
\hline
\end{tabular}

Fonte: Elaborado pelas autoras

* Dois entrevistados não responderam a esta pergunta.

Segundo a Tabela 4, nenhum dos agricultores pesquisados do município de Cândido Godói se desloca para fazer a revisão de seu maquinário, o que indica que nesta cidade a oferta desse tipo de serviço é satisfatória aos entrevistados. No município de Santo Cristo, $85,7 \%$ dos respondentes realizam a revisão no próprio município, e os demais realizam este tipo de serviço em Santa Rosa. Já no município de Alecrim, apenas $60 \%$ realizam a manutenção no próprio município, e os demais se deslocam para Santa Rosa, Santo Cristo e Horizontina para realizar a manutenção em concessionárias.

A Tabela 5 procura identificar a percepção dos agricultores com relação ao preço das peças e implementos agrícolas em cada município investigado. Essa análise pode contribuir para que se compreendam melhor os resultados da Tabela 4.

\section{Tabela 5 - Frequência da percepção de preços entre os três municípios*.}

\begin{tabular}{ccc|ccc|ccc}
\hline \multirow{2}{*}{ Cidade } & \multicolumn{2}{c}{$\begin{array}{c}\text { Revisão do } \\
\text { maquinário }\end{array}$} & \multicolumn{3}{c}{ Troca de peças } & \multicolumn{2}{c}{ Implementos agrícolas } \\
\cline { 2 - 8 } & Adeq & Caro & Barato & Adeq. & Caro & Barato & Adeq. & Caro \\
\hline Santo & 3 & 12 & 0 & 3 & 12 & 0 & 4 & 11 \\
Cristo & $(20 \%)$ & $(80 \%)$ & & $(20 \%)$ & $(80 \%)$ & & $(27 \%)$ & $(73 \%)$ \\
Când. & 11 & 13 & 0 & 8 & 16 & 0 & 10 & 13 \\
Godói & $(46 \%)$ & $(54 \%)$ & & $(33 \%)$ & $(67 \%)$ & & $(43 \%)$ & $(57 \%)$ \\
& 15 & 10 & 1 & 10 & 14 & 1 & 8 & 16 \\
Alecrim & $(60 \%)$ & $(40 \%)$ & $(4 \%)$ & $(40 \%)$ & $(56 \%)$ & $(4 \%)$ & $(32 \%)$ & $(64 \%)$ \\
& 29 & 35 & 1 & 21 & 42 & 1 & 22 & 40 \\
Total & $(45,3 \%)$ & $(54,7 \%)$ & $(1,6 \%)$ & $(32,8 \%)$ & $(65,6 \%)$ & $(1,6 \%)$ & $(34,9 \%)$ & $(63,5 \%)$ \\
\hline
\end{tabular}

Fonte: Elaborado pelas autoras.

${ }^{1}$ Adeq. (abreviação de "Adequado")

*No município de Cândido Godói algumas questões não foram respondidas

Analisando-se o município de Alecrim, percebe-se que a maioria dos respondentes (60\%) aponta que a revisão do maquinário possui um preço adequado 
e $44 \%$ e $36 \%$ percebem o preço da troca de peças e dos implementos agrícolas, respectivamente, como barato ou adequado. Já nos outros dois municípios, a maior parte dos respondentes indica que os preços das revisões, das trocas de peças e dos implementos são caros. Este resultado pode justificar aquele encontrado na Tabela 4, de que em Alecrim há mais casos de agricultores que realizam a manutenção fora de seu município, podendo realizar "pesquisa de preço" antes de contratar o serviço, não sendo a percepção do preço tão alto para esses respondentes. Já nos municípios de Cândido Godói e Santo Cristo percebe-se que boa parte dos agricultores opta pela comodidade de utilizar o serviço ofertado pelas empresas localizadas na própria cidade, mesmo que haja a percepção de preço mais elevada.

Nota-se também, na Tabela 5, que, referente à revisão do maquinário, nenhum dos respondentes marcou a alternativa "barato", demonstrando que há uma similaridade de percepções em relação ao preço. $\mathrm{Na}$ avaliação do preço da revisão, a maioria dos respondentes (54,7\%), independente do município, aponta que este tipo de serviço é caro.

Com o ato da revisão do maquinário (manutenção preventiva), tem-se a necessidade de trocar algumas peças, que podem apresentar o risco de interromper o processo de utilização da máquina/implemento como um todo. Ao avaliar o preço das peças que precisam ser trocadas, $65,6 \%$ dos respondentes julgaram caro. Isto pode ser justificado pela necessidade de utilizar peças originais para a reposição, a fim de se ter o melhor funcionamento do equipamento.

Indiferente do município, mais de $60 \%$ acreditam que o preço das peças e implementos é caro. Uma das possíveis justificativas, de acordo com os entrevistados, é que se comparar o preço de uma semeadora nova, por exemplo, com o preço de um carro novo, a diferença é muito significativa. Conforme Stefanoski et al. (2013), o que impede, muitas vezes, os agricultores de inovar no meio rural é o preço elevado de aquisição da nova tecnologia.

A partir da identificação de que uma parte dos agricultores não compra em apenas um município, buscou-se melhor compreender em que municípios realizam a aquisição dos produtos e serviços que necessitam. Na Tabela 6 são apresentadas essas relações. Nesta Tabela a soma das porcentagens também é superior a $100 \%$, pois os agricultores tinham a opção de assinalar mais de uma alternativa, indicando que se deslocam para comprar em mais de um município.

Tabela 6 - Município em que os agricultores pesquisados compram as peças

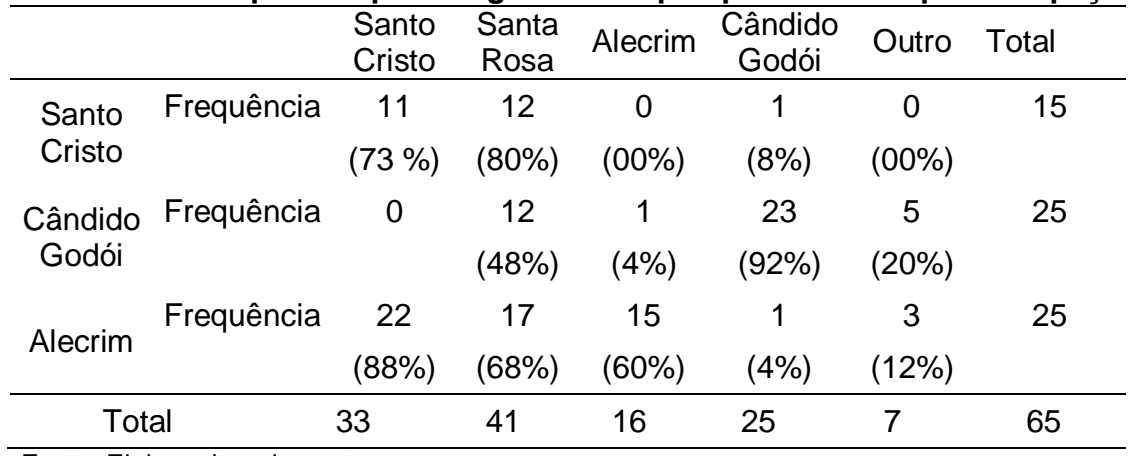

Fonte: Elaborado pelas autoras. 
No município de Santo Cristo, a maioria dos respondentes realizam suas compras ou no próprio município ou na cidade de Santa Rosa. Apenas um respondente se desloca para Cândido Godói. No município de Alecrim percebe-se uma evasão maior para as compras das peças, sendo que $88 \%$ dos respondentes se deslocam para Santo Cristo e, ainda, $68 \%$ se deslocam para Santa Rosa para efetuar suas compras. Percebe-se, neste município, um espaço no mercado que ainda não foi preenchido. Já no município de Cândido Godói, 92\% dos respondentes efetuam suas compras no próprio município e, aproximadamente, $48 \%$ deles também se deslocam para Santa Rosa para fazerem as compras. Vale ressaltar que o município de Santa Rosa é o município que recebe $63,1 \%$ dos entrevistados para realizar as compras de peças, uma possível justificativa para esse fato é que no município de Santa Rosa está instalada uma empresa multinacional, AGCO do Brasil Ltda., a qual produz e distribui produtos agrícolas de diferentes marcas (CASTILHOS et al., 2008).

O fato de os agricultores não encontrarem (nos municípios pequenos) todos os produtos e serviços que precisam, é facilmente explicado. Cada empresa tem seu conjunto específico de peças, que formam um todo (máquina ou implemento agrícola). Um produto de uma empresa pode ter variações, como por exemplo, uma semeadora pode ser fabricada exclusivamente para soja ou exclusivamente para trigo e cada uma destas requer um conjunto específico de peças. Assim, é preciso que os estabelecimentos comerciais que trabalham com esses tipos de produtos tenham em seu estoque um número razoável de marcas e suas subdivisões.

A fim de melhor compreender o comportamento desses consumidores de produtos e serviços agrícolas, é apresentado na Tabela 7 o motivo que leva os agricultores a comprar em determinado estabelecimento. Esta Tabela também apresenta índices maiores de cem por cento (100\%) no total de cada coluna, pois a escolha do estabelecimento é avaliada por mais de um ângulo.

\begin{tabular}{lcccc}
$\begin{array}{l}\text { Tabela } 7 \text { - Análise do motivo que leva os agricultores a comprar em } \\
\text { determinado estabelecimento }\end{array}$ & \multicolumn{4}{c}{ Município } \\
\cline { 2 - 5 } Motivo & Santo Cristo & $\begin{array}{c}\text { Cândido } \\
\text { Godói }\end{array}$ & Alecrim & Total \\
\cline { 2 - 5 } & 2 & 2 & 11 & 15 \\
Preços baixos & $(13 \%)$ & $(13 \%)$ & $(74 \%)$ & \\
Localização & 1 & 7 & 1 & 9 \\
Qualidade dos produtos & $(11 \%)$ & $(78 \%)$ & $(11 \%)$ & 48 \\
Qualidade no & 11 & 16 & 21 & 48 \\
atendimento & $(23 \%)$ & $(33 \%)$ & $(44 \%)$ & 18 \\
Poucos Concorrentes & 4 & 4 & 10 & 18 \\
Outro & $(22 \%)$ & $(22 \%)$ & $(56 \%)$ & 7 \\
\hline Total & 3 & 3 & 1 & \\
& $(43 \%)$ & $(43 \%)$ & $(14 \%)$ & 6 \\
\hline
\end{tabular}

Fonte: Elaborado pelas autoras. 
Para realizar a compra, os agricultores pesquisados, independente do município, priorizam a qualidade dos produtos $(74 \%)$, seguida da qualidade no atendimento (28\%) e dos preços baixos (23\%). Ao priorizarem a qualidade dos produtos, muitas vezes é preciso "abrir mão" dos preços baixos, este resultado vai ao encontro do que foi apresentado na Tabela 4, a qual mostra que mais de $60 \%$ dos respondentes acreditam pagar caro pelos produtos que compram.

Em relação aos preços baixos, o município de Alecrim teve um maior percentual de respostas do que os demais municípios, com 73,3\%. Este resultado corrobora a discussão anteriormente realizada, a partir das constatações das Tabelas 4 e 5 . A localização foi um motivo relevante apenas para os agricultores do município de Cândido Godói, o que pode estar relacionado ao fato de esses agricultores comprarem grande parte das peças e implementos que necessitam na própria cidade.

O motivo referente à qualidade dos produtos foi destacado por $43,8 \%$ dos respondentes do município de Alecrim. A qualidade no atendimento também é prioridade para esses agricultores, sendo destacado por $55,6 \%$ deles. Já o motivo de haver poucos concorrentes para escolher um estabelecimento, é levado em consideração por 42,9\% dos agricultores dos municípios de Cândido Godói e de Santo Cristo. Já na opção outros, os respondentes indicaram que levam em consideração, no momento da compra, os estabelecimentos que disponibilizam, por exemplo, a assistência técnica após a compra. Em pesquisa realizada com agricultores de Marau (RS), foi identificado que características como "durabilidade, qualidade, vida útil do bem, facilidade de manutenção, baixo custo operacional, facilidade na aquisição de peças, cumprimento das garantias dos produtos novos" são itens levados em consideração na hora de adquirir uma máquina agrícola (KASPARY et al., 2008, p. 1).

Ainda, buscou-se identificar a percepção dos agricultores com relação às empresas que vendem os produtos e prestam os serviços relacionados à atividade agrícola, diferenciando-os conforme o tamanho das suas propriedades. Para poder identificar se havia diferença nas médias nos três tipos de tamanho das propriedades pesquisadas, foi aplicado o teste Anova. "Anova é um teste de hipóteses de médias de duas ou mais populações" (LAPPONI, 2000 p. 365), este é um procedimento útil para comparação. Os entrevistados tiveram que responder de acordo com o grau de concordância, para cada uma das assertivas destacadas na Quadro 2, utilizando uma Escala do tipo Likert com a seguinte classificação: 1 Discordo, 2 Discordo Parcialmente, 3 Indiferente, 4 Concordo Parcialmente e 5 Concordo. Na Tabela 8 são apresentados o resultados para cada uma das assertivas apresentadas no Quadro 2. 
Quadro 2 - Questões apresentadas aos agricultores.

\begin{tabular}{|r|l|}
\hline \multicolumn{1}{|c|}{ Código } & \multicolumn{1}{|c|}{ Questão } \\
\hline 1 & $\begin{array}{l}\text { A localização da empresa em que compro produtos para minha } \\
\text { propriedade facilita o acesso para os clientes. }\end{array}$ \\
\hline 2 & A empresa é pontual na entrega dos produtos \\
\hline 3 & As condições de pagamento atendem às expectativas dos clientes. \\
\hline 4 & $\begin{array}{l}\text { Quando a empresa se compromete em fazer algo em um determinado } \\
\text { tempo ela cumpre. }\end{array}$ \\
\hline 5 & O produto adquirido corresponde às condições contratadas. \\
\hline 6 & $\begin{array}{l}\text { Quando o cliente tem dúvidas ou problemas, a empresa demonstra } \\
\text { atenção especial e interesse em resolvê-los. }\end{array}$ \\
\hline 7 & A empresa tem instalações físicas agradáveis. \\
\hline 8 & $\begin{array}{l}\text { A empresa transmite ao cliente segurança, confiança e conhecimento do } \\
\text { produto no atendimento. }\end{array}$ \\
\hline 9 & $\begin{array}{l}\text { A divulgação através dos meios de comunicação (rádio e jornal) é de } \\
\text { fácil compreensão. }\end{array}$ \\
\hline 10 & A variedade de produtos satisfaz a expectativa dos clientes. \\
\hline 11 & A empresa opera em horário conveniente. \\
\hline 12 & $\begin{array}{l}\text { Os produtos estão expostos de forma organizada, não confundem o } \\
\text { cliente. }\end{array}$ \\
\hline 13 & A empresa fornece crédito fácil e diferenciado aos seus clientes. \\
\hline 14 & $\begin{array}{l}\text { A equipe de funcionários demonstra competência, segurança e precisão } \\
\text { na hora de executar as suas atividades. }\end{array}$ \\
\hline 15 & $\begin{array}{l}\text { Os vendedores oferecem aos clientes tratamento personalizado, cordial } \\
\text { e eficiente. }\end{array}$ \\
\hline 16 & $\begin{array}{l}\text { Após a entrega do produto comprado, o cliente recebe o mesmo } \\
\text { tratamento personalizado, cordial e eficiente. }\end{array}$ \\
\hline
\end{tabular}

Fonte: Elaborado pelas autoras.

Na Tabela 8 são apresentados o resultados para cada uma das assertivas apresentadas no Quadro 2. 
Tabela 8 - Resultados comparativos entre as propriedades de diferentes tamanhos quanto às empresas que as atendem.

\begin{tabular}{|c|c|c|c|c|c|c|}
\hline \multirow[b]{2}{*}{ Questão } & \multirow{2}{*}{ Tamanho da propriedade } & \multirow{2}{*}{ Respondentes } & \multirow{2}{*}{ Média } & \multirow{2}{*}{$\begin{array}{l}\text { Desvio } \\
\text { Padrão }\end{array}$} & \multicolumn{2}{|c|}{ Anova } \\
\hline & & & & & $\mathrm{F}$ & Sig \\
\hline \multirow{4}{*}{1} & Até 30 ha & 25 & 4,16 & 0,987 & \multirow{4}{*}{5,186} & \multirow{4}{*}{0,008} \\
\hline & De 30 ha a 50 ha & 19 & 4,53 & 0,772 & & \\
\hline & Mais de 50 ha & 20 & 4,90 & 0,308 & & \\
\hline & Total & 64 & 4,50 & 0,816 & & \\
\hline \multirow{3}{*}{2} & Até 30 ha & 25 & 4,40 & 0,707 & \multirow{3}{*}{0,233} & \multirow{3}{*}{0,793} \\
\hline & $\begin{array}{l}\text { De } 30 \text { ha a } 50 \text { ha } \\
\text { Mais de } 50 \text { ha }\end{array}$ & $\begin{array}{l}19 \\
20\end{array}$ & $\begin{array}{l}4,21 \\
4,30\end{array}$ & $\begin{array}{l}0,976 \\
1,081\end{array}$ & & \\
\hline & Total & 64 & 4,31 & 0,906 & & \\
\hline \multirow{4}{*}{3} & Até 30 ha & 25 & 4,24 & 1,012 & \multirow{4}{*}{0,713} & \multirow{4}{*}{0,494} \\
\hline & De 30 ha a 5 ha & 19 & 4,53 & 0,697 & & \\
\hline & Mais de 50 ha & 20 & 4,45 & 0,686 & & \\
\hline & Total & 64 & 4,39 & 0,828 & & \\
\hline \multirow{4}{*}{4} & Até 30 ha & 25 & 4,04 & 1,136 & \multirow{4}{*}{0,154} & \multirow{4}{*}{0,857} \\
\hline & $5 \mathrm{De} 30$ ha a 5 ha & 19 & 4,21 & 0,976 & & \\
\hline & Mais de 50 ha & 20 & 4,05 & 1,146 & & \\
\hline & Total & 64 & 4,09 & 1,08 & & \\
\hline \multirow{4}{*}{5} & Até 30 ha & 25 & 4,40 & 1 & & \\
\hline & De 30 ha a 5 ha & 19 & 4,74 & 0,452 & & \\
\hline & Mais de 50 ha & 20 & 4,60 & 0,754 & 1,003 & 0,373 \\
\hline & Total & 64 & 4,56 & 0,794 & & \\
\hline & Até 30 ha & 25 & 4,24 & 0,663 & & \\
\hline & De 30 ha a 5 ha & 19 & 4,37 & 0,684 & & \\
\hline 6 & Mais de 50 ha & 20 & 4,50 & 0,889 & 0,676 & 0,512 \\
\hline & Total & 64 & 4,36 & 0,743 & & \\
\hline & Até 30 ha & 25 & 4,24 & 1,091 & & \\
\hline 7 & De 30 ha a 5 ha & 17 & 4,35 & 0,931 & 0109 & 0.897 \\
\hline 7 & Mais de 50 ha & 20 & 4,20 & 1,005 & 0,109 & 0,891 \\
\hline & Total & 62 & 4,26 & 1,007 & & \\
\hline & Até 30 ha & 25 & 4,24 & 0,779 & & \\
\hline 0 & De 30 ha a 5 ha & 19 & 4,32 & 1,003 & & \\
\hline 8 & Mais de 50 ha & 20 & 4,05 & 1,234 & 0,368 & 0,693 \\
\hline & Total & 64 & 4,20 & 0,995 & & \\
\hline & Até 30 ha & 25 & 4,00 & 1,155 & & \\
\hline 9 & De 30 ha a 5 ha & 19 & 3,53 & 1,124 & 1682 & 0195 \\
\hline$y$ & Mais de 50 ha & 20 & 4,15 & 1,04 & 1,682 & 0,195 \\
\hline & Total & 64 & 3,91 & 1,123 & & \\
\hline & Até 30 ha & 25 & 3,96 & 0,978 & & \\
\hline & De 30 ha a 5 ha & 19 & 4,21 & 0,976 & & \\
\hline 10 & Mais de 50 ha & 20 & 4,00 & 1,026 & 0,376 & 0,688 \\
\hline & Total & 64 & 4,05 & 0,983 & & \\
\hline & Até 30 ha & 24 & 4,42 & 0,83 & & \\
\hline & De 30 ha a 5 ha & 18 & 4,50 & 0,786 & & \\
\hline 11 & Mais de 50 ha & 20 & 4,50 & 1 & 0,066 & 0,936 \\
\hline & Total & 62 & 4,47 & 0,863 & & \\
\hline & Até 30 ha & 24 & 4,00 & 1,063 & & \\
\hline & De 30 ha a 5 ha & 19 & 4,05 & 0,97 & & \\
\hline 12 & Mais de 50 ha & 19 & 4,11 & 1,049 & 0,055 & 0,946 \\
\hline & Total & 62 & 4,05 & 1,015 & & \\
\hline & Até 30 ha & 25 & 4,08 & 1,187 & & \\
\hline 13 & De 30 ha a 5 ha & 18 & 4,11 & 1,079 & $0 \cap 005$ & \\
\hline 13 & Mais de 50 ha & 19 & 4,11 & 0,809 & 0,005 & 0,995 \\
\hline & Total & 62 & 4,10 & 1,036 & & \\
\hline
\end{tabular}


Tabela 8 - Resultados comparativos entre as propriedades de diferentes tamanhos quanto às empresas que as atendem

\begin{tabular}{|c|c|c|c|c|c|c|}
\hline \multirow[b]{2}{*}{ Questão } & \multirow{2}{*}{ Tamanho da propriedade } & \multirow{2}{*}{ Respondentes } & \multirow{2}{*}{ Média } & \multirow{2}{*}{$\begin{array}{l}\text { Desvio } \\
\text { Padrão }\end{array}$} & \multicolumn{2}{|c|}{ Anova } \\
\hline & & & & & $\mathrm{F}$ & Sig \\
\hline \multirow{4}{*}{14} & Até 30 há & 25 & 4,04 & 1,06 & \multirow{4}{*}{1,105} & \multirow{4}{*}{0,338} \\
\hline & De 30 ha a 5 ha & 19 & 4,53 & 0,841 & & \\
\hline & Mais de 50 ha & 20 & 4,15 & 1,348 & & \\
\hline & Total & 64 & 4,22 & 1,105 & & \\
\hline \multirow{4}{*}{15} & Até 30 ha & 25 & 4,00 & 0,957 & \multirow{4}{*}{0,896} & \multirow{4}{*}{0,414} \\
\hline & De 30 ha a 5 ha & 19 & 4,21 & 0,787 & & \\
\hline & Mais de 50 ha & 20 & 4,35 & 0,875 & & \\
\hline & Total & 64 & 4,17 & 0,883 & & \\
\hline \multirow{4}{*}{16} & Até 30 ha & 25 & 3,84 & 1,434 & \multirow{4}{*}{0,150} & \multirow{4}{*}{0,861} \\
\hline & De 30 ha a 5 ha & 19 & 4,05 & 1,311 & & \\
\hline & Mais de 50 ha & 20 & 4,00 & 1,298 & & \\
\hline & Total & 64 & 3,95 & 1,338 & & \\
\hline
\end{tabular}

Fonte: Elaborado pelas autoras.

Apenas para a questão 1 , referente à localização da empresa, percebe-se diferença significativa (sig. $<0,05$ ) para o teste Anova, entre os diferentes tamanhos de propriedade. Este resultado indica que os proprietários de áreas rurais com maior extensão possuem pensamentos divergentes dos que possuem médias e pequenas propriedades. Este resultado pode ser explicado pelo fato de os proprietários de grandes extensões de terra possuir maior facilidade para chegar até as empresas onde realizam suas compras, pois quanto maior a quantidade de produtos comprados, menor é o custo unitário do frete.

Nas demais perguntas apresentadas na Tabela 8, não foram identificadas diferenças significativas entre as percepções dos respondentes de propriedades com diferentes portes, indicando que não há divergência entre os modos de pensamento dos proprietários pesquisados.

\section{CONSIDERAÇÕES FINAIS}

Este estudo realizou uma discussão acerca da percepção dos agricultores dos municípios de Alecrim, Cândido Godói e Santo Cristo, localizados na região de Santa Rosa - RS, sobre a estrutura comercial no setor de máquinas e implementos agrícolas, que os atende e fornece subsídios para o desenvolvimento de suas atividades. Para tanto, utilizou-se o método survey para a coleta dos dados com 65 agricultores desses municípios. Caracterizando-se as propriedades investigadas, tem-se que, as do município de Alecrim são, majoritariamente, de médio porte, sendo que $40 \%$ das propriedades possuem entre 30 ha. a 50 ha. Já em Cândido Godói, das 25 propriedades pesquisadas, $46 \%$ possuem mais de 50 há, e, em Santo Cristo, $47 \%$ das propriedades possuem até 30 ha. Nestes espaços de terra são cultivados, principalmente, milho, soja e trigo. Os maquinários mais utilizados são o trator, o pulverizador, a plantadora e o distribuidor de fertilizante.

A fim de atender ao objetivo geral deste estudo, foram realizadas diferentes análises, dentre elas: a verificação dos locais (na propriedade rural, oficina mecânica, concessionária) que os agricultores costumam fazer a manutenção dos seus maquinários; a cidade em que os agricultores realizam a revisão e/ou a manutenção de seus equipamentos; as percepções de preço sobre as revisões e manutenções do maquinário, da troca de peças e dos implementos agrícolas; as cidades em que predominantemente compram as peças agrícolas; os motivos que 
levam os agricultores a comprar em determinado estabelecimento; e, por fim, foi realizada uma análise estatística, através do teste Anova, para verificar se há diferença entre as percepções dos agricultores donos de propriedades rurais com diferentes portes quanto às empresas que os atendem.

De um modo geral, independentemente do município, $60 \%$ dos agricultores preferem realizar a manutenção em sua propriedade e apenas $7 \%$ realiza a manutenção em uma concessionária. Os agricultores de Cândido Godói preferem realizar a revisão de seu maquinário nas concessionárias do município, assim como boa parte dos agricultores de Santo Cristo (85,7\%); enquanto que $60 \%$ dos agricultores de Alecrim realizam a manutenção no próprio município, e os demais se deslocam para outras cidades para ter acesso a este serviço.

Considerando os respondentes dos três munícipios, percebeu-se que a cidade de Santa Rosa, por ter uma grande quantidade de empresas instaladas no ramo agrícola, é a que mais suporta a demanda desses agricultores, quando não compram em seus municípios. Todos os municípios pesquisados possuem oferta de produtos (implementos, peças, máquinas e serviços), mas esta oferta é limitada, com apenas algumas marcas, acarretando no deslocamento dos agricultores a outros municípios para suprir as necessidades. Ainda, com relação aos motivos que levam esses agricultores a escolher um estabelecimento comercial, tem-se destaque para a qualidade dos produtos e do atendimento oferecidos, bem como o fato de haver poucos concorrentes para escolher um estabelecimento. Esses resultados são interessantes para empresas da região, atuantes neste ramo, a fim de melhorar sua oferta de produtos e serviços, bem como buscar maior competitividade.

Por fim, realizou-se uma análise comparativa de percepção dos agricultores por porte da propriedade rural. Encontrou-se que, os proprietários de maiores extensões de terra tendem a concordar com o fato de que é adequada a localização da empresa em que compram produtos para suas propriedades, diferentemente dos agricultores de menores propriedades.

Este estudo consistiu em uma exploração inicial acerca da percepção de parte dos agricultores da região de Santa Rosa, havendo a limitação de a amostra não ser representativa, o que não permite que os resultados sejam compreendidos como válidos para a população. Entretanto, entende-se que os achados discutidos neste estudo já possuem condições de fornecer subsídios para os empresários do setor de implementos e máquinas agrícolas da região investigada, contribuindo para que desenvolvam estratégias competitivas para atender seu público-alvo.

A partir desta limitação, sugere-se que este estudo seja ampliado, utilizando-se de uma amostragem do tipo probabilística, a fim de possibilitar uma compreensão mais realista da população em estudo e informações mais acuradas aos empresários da região. Questões inicialmente trabalhadas neste estudo ainda precisam ser melhor discutidas, como o fato de esses agricultores estarem aptos a pagar pela comodidade de ter em seu município um serviço mais completo de atendimentos às suas necessidades, bem como quais os serviços imprescindíveis que necessitam ser oferecidos em seus municípios, para melhor acesso. Também, sugere-se que pesquisas semelhantes a esta sejam realizadas em outras regiões do estado do Rio Grande do Sul, para fins de comparações de resultados e melhor compreensão desta categoria de consumidores. Ainda, seguindo a perspectiva dos trabalhos de Mallmann e Lago (2012) e Schimidt e Godinho (2006), é salutar ampliar esta investigação para melhor compreender quais as consequências causadas com a modernização das técnicas de cultivo nos três municípios investigados neste estudo. 


\section{REFERÊNCIAS}

AAKER, D. A., KUMAR V., DAY, G. S. Pesquisa de marketing. Traduzido por Reynaldo Cavalheiro Marcondes. 2. ed. São Paulo: Atlas, 2011.

ALCÂNTARA FILHO, J.; FONTES, R. M. O. A formação da propriedade e a concentração de terras no Brasil. Revista de História Econômica e Economia Regional Aplicada. v.4. n. 7. Jul-Dez 2009. Disponível em:

http://www.ufff.br/heera/files/2009/11/ESTRUTURA-FUNDI\%C3\%81RIA-ze-luisparapdf.pdf. Acesso em 07 de julho de 2015.

ALONÇO, A. S. MACHADO, A. L. T.; FERREIRA, M. F. P. Máquinas para fenação. Pelotas: Editora Universitária, 2004. ANPAD. Rio de Janeiro, 2007.

BOTTEGA, E. L. et al. Aquisição de uma colhedora combinada de grãos: estudo de viabilidade para a região de farol, PR, no ano agrícola de 2012. 2015. Disponível em:

http://www.researchgate.net/profile/Eduardo_Bottega/publication/279181634_AQUIS IO_DE_UMA_COLHEDORA_COMBINADA_DE_GROS_ESTUDO_DE_VIABILIDAD E_PARA_A_REGIO_DE_FAROL_PR_NO_ANO_AGRCOLA_DE_2012/links/558cae 6e08ae40781c2057f6.pdf. Acesso em 18 de outubro de 2015.

BRUM, A. L.; LUFT, A. Aspectos da cadeia produtiva do milho e as relações comerciais nos estados do rio grande do sul e mato grosso (1994/95-2005/06). Extensão Rural, v.15, n. 16, $2008 . \quad$ Disponível em: http://w3.ufsm.br/extensaorural/art5ed16.pdf. Acesso em 13 de outubro de 2015.

CASTILHOS, C. C. Bons resultados para a indústria de máquinas e equipamentos agrícolas do RS. Indicadores Econômicos da FEE, v. 35, n. 2, p. 55-60, out. 2007. Disponível em:

http://revistas.fee.tche.br/index.php/indicadores/article/viewFile/1559/1928. Acesso em 22 de julho de 2015.

CASTILHOS, C. C. et al. A indústria de máquinas e implementos agrícolas (MIA) no RS: notas sobre a configuração recente. Disponível em: http://revistas.fee.tche.br/index.php/ensaios/article/view/2185/2579. Acesso em 07 de julho de 2015.

COOPER, D. R.; SCHINDLER, P. S. Métodos de Pesquisa em Administração, 10 ed. Porto Alegre: Bookman, 2011.

DANTAS, W. Interpretação das definições de termos de Manutenção estabelecidos pela Norma ABNT NBR 5462: manitencabilidade e confiabilidade. 2010. Disponível em: http://www.webartigos.com/artigos/interpretacao-dasdefinicoes-de-termos-de-manutencao-estabelecidos-pela-norma-abnt-nbr-5462manutenabilidade-e-confiabilidade/35445/. Acesso em: 11 de dezembro de 2013.

FELIPE, F. I.; LIMA, R. A. S.; RODRIGUES, S. M. Evolução da estrutura da indústria de tratores de rodas, no Brasil, no período de 1999 a $2008.47^{\circ}$ Congresso SOBER - Sociedade Brasileira de Economia, Administração e Sociologia Rural. Porto Alegre, $2009 . \quad$ Disponível em: 
http://cepea.esalq.usp.br/pdf/Evolucao_estrutura.pdf. Acesso em: 30 de julho de 2015.

FERO, A. O setor de máquinas agrícolas no Brasil: evolução nos últimos anos e perspectivas. 2014. Disponível em: http://celeres.com.br/o-setor-de-maquinasagricolas-no-brasil-evolucao-nos-ultimos-anos-e-perspectivas/. Acesso em 20 de julho de 2015.

FERREIRA, A. B. H. Mini Aurélio: o dicionário da língua portuguesa. Coordenação de edição Marina Baird Ferreira, 8. ed. Curitiba: Positivo, 2010.

FERREIRA, M. F. P. et al. Máquinas para silagem. Pelotas: Editora Universitária, 2003.

GASQUES, J. G.; BASTOS, E. T. Crescimento da agricultura. IPEA Boletim de Conjuntura | 60 | mar 2003. Disponível em

http://www.ie.ufrj.br/hpp/intranet/pdfs/01_crescimento_da_agricultura.pdf. Acesso em 08 de julho de 2014.

Google Mapas (2015). Disponível em: https://www.google.com.br/maps. Acesso em 18 de julho de 2015.

GRAEF, C. E.; BÜTTENBENDER, P. L. O papel das cooperativas na estrutura de governança do sistema agroindustrial do leite na região fronteira noroeste do Rio Grande do Sul. 2014.2 Disponível em: http://bibliodigital.unijui.edu.br:8080/xmlui/bitstream/handle/123456789/2870/TCC\%2 0-\%20Cleber\%20Graef\%20-

\%20Vers\%C3\%A30\%20Final\%20\%28Usu\%C3\%A1rio\%20Cl\%C3\%A9ber\%20Graef $\% 29 \% 20 \% 28$ Data\%2004-12-2014\%2021h28m\%29\%20TCC\%20-

$\% 20$ Cleber\%20Graef\%20-

\%20Vers\%C3\%A30\%20Final\%20\%281\%29.pdf?sequence=1. Acesso em 15 de outubro de 2015 .

HAIR JUNIOR, J. F. et al. Fundamentos de métodos de pesquisa em administração. Porto Alegre: Bookman, 2005.

Instituto Brasileiro de Geografia e Estatística (2010). Disponível em: http://www.ibge.gov.br/home/. Acesso em 13 de janeiro de 2014.

KASPARY, I. M. et al. Atributos influenciadores na decisão de compra de máquinas agrícolas: um estudo de caso junto aos agricultores da cidade de Marau/RS. Disponível em: http://gpi.aedb.br/seget/artigos09/305_305_Trator_SEGET_2009.pdf. Acesso em 18 de outubro de 2015.

KIRCHNER, R. M. et al. Avaliação da qualidade de serviços de uma empresa agrícola. Revista Brasileira de Gestão e Desenvolvimento Regional, v. 8, jan-abr. 2012.

LAPPONI, J. C. Estatística usando Excel. São Paulo: Lapponi Treinamento e Editora, 2000. 
MACHADO, A. L. T. et al. Máquina para preparo do solo, semeadura, adubação e tratamento culturais. 2. Ed., Pelotas: Editora Universitária, 2005

MALHOTRA, N. K. Pesquisa de marketing: uma orientação aplicada, 6.ed. Porto Alegre: Bookman, 2012.

MALLMANN, M. S.; LAGO, I. C. Os agricultores e a "modernidade": uma análise da relação entre cultura e tecnologia no meio rural de Cerro Largo/RS. Extensão Rural, Santa Maria, v.19, n. 1, jan./jun. 2012. Disponível em: http://cascavel.ufsm.br/revistas/ojs2.2.2/index.php/extensaorural/article/view/6538.

Acesso em: 8 jul. 2015.

MATTAR, F. N. Pesquisa de marketing: metodologia planejamento, 6. Ed. São Paulo: Atlas, 2005.

MAZOYER, M.; ROUDART, L. Histórias das agriculturas do mundo: do neolítico à crise contemporânea. São Paulo: Instituto Piaget, 2001.

PASQUAL, C. A.; PEDROZO, E. Á. Características do negócio no setor de máquinas agrícolas. ERA-Eletrônica, v. 6, n. 1, art. 3, jan/jun.2007. Disponível em: http://www.lume.ufrgs.br/bitstream/handle/10183/20528/000624274.pdf?sequence $=1$ Acesso em 07 de julho de 2015.

PEDÓ, C. A.; ESTEVES, G. C. Melhoria de projeto na cobertura do tanque graneleiro de uma colheitadeira de grãos John Deere. (2013). Disponível em: http://www.fahor.com.br/publicacoes/TFC/EngMec/2013/Mec_Cleber_Gelson.pdf.

Acesso em 24 de setembro de 2014.

PONTUAL, D. H. Reforma do Código Florestal: Agência Senado. (2011). Disponível em: http://www12.senado.gov.br/codigoflorestal/news/entenda-osprincipais-termos-utilizados-na-discussao-do-novo-codigo-florestal. Acesso em 13 de janeiro de 2014.

PUDELL, V. Análise da gestão da pequena propriedade rural: o caso dos produtores de leite da região do grande santa rosa - RS. (2006). Disponível em: http://cascavel.ufsm.br/tede/tde_arquivos/12/TDE-2006-12-12T085117Z281/Publico/Valmir\%20Pudell.pdf. Acesso em 15 de outubro de 2015.

REDIN, E. Dentro e fora da porteira- os elementos condicionantes na estratégia de reprodução dos agricultores familiares fumageiros. Extensão Rural, Santa Maria, v. 18, n. 22, jul./dez. 2011. Disponível em: http://cascavel.ufsm.br/revistas/ojs2.2.2/index.php/extensaorural/article/view/5649/3342. Acesso em: 13 out. 2015.

REIS, Â. V. et al. Motores, tratores, combustíveis e lubrificantes, 2. Ed. Pelotas: Editora Universitária, 2005.

SANTOS FILHO, A. G.; SANTOS, J. E. G. G. Apostila de máquinas agrícolas. 2001. Disponível em: http://wwwp.feb.unesp.br/abilio/maqagri.pdf Acesso em 12 de dezembro de 2013.

SCHMIDT, M. L. G.; GODINHO, P. H. Um breve estudo acerca do cotidiano do trabalho de produtores rurais: intoxicações por agrotóxicos e subnotificação. Revista 
Brasileira de Saúde Ocupacional. São Paulo, 2006. Disponível em: http://www.scielo.br/scielo.php?script=sci_arttext\&pid=S030376572006000100004\&l $\mathrm{ng}=\mathrm{pt} \& \mathrm{nrm}=\mathrm{iso} \& \mathrm{t} \mathrm{ng}=\mathrm{pt}$. Acesso em 08 de julho de 2015.

SILVA, E. L. MENEZES, E. M. Metodologia da pesquisa e elaboração de dissertação,- 4. Ed. Florianópolis: UFSC, 2005. Disponível em: http://www.convibra.com.br/upload/paper/adm/adm 3439.pdf. Acesso em 10 de dezembro de 2013.

SILVEIRA, G. M. As máquinas de plantar: aplicadoras, distribuidoras, semeadoras, plantadoras, cultivadoras. Rio de Janeiro: Globo, 1989.

Site EMATER Santa Rosa RS. Disponível em: http://www.emater.tche.br/site/regionais/santa-rosa.php\#.VBCik_IdVe8. Acesso em 10 de setembro de 2014.

STADUTO, J. A. R.; KRETER, A. C. A questão agrária e o mercado de trabalho rural. VIII Congreso Latinoamericano de Sociologia Rural 2010. Disponível em: http://www.alasru.org/wp-content/uploads/2011/09/GT21-Jefferson-AndronioRamundo-Staduto.pdf. Acesso em 08 de julho de 2014.

STEFANOSKI, D. C. et al. Inovação tecnológica: análise no assentamento Banco da Terra, em nova Xavantina - MT. Extensão Rural, Santa Maria, v. 21, n. 3, set./dez. 2013. Disponível em: http://cascavel.ufsm.br/revistas/ojs2.2.2/index.php/extensaorural/article/view/7311/pdf_1. Acesso em 13 de outubro de 2015.

VEGRO, C. L. R.; FERREIRA, C. R. R.P.T. Mercado de máquinas agrícolas automotrizes: alta dos suprimentos estratégicos. Análises e Indicadores do Agronegócio. v.3, n.7, julho, 2008. Disponível em: ftp://ftp.sp.gov.br/ftpiea/AIA/AIA56-2008.pdf. Acesso em: 30 de julho de 2015.

VIAN, C. E. F. et al. Origens, evolução e tendências da indústria de máquinas agrícolas. Revista de Economia e Sociologia Rural, v. 51, n. 4, Brasília Out./Dez. 2013. Disponível em: http://www.scielo.br/scielo.php?script=sci_arttext\&pid=S010320032013000400006\&lang=pt\#tx02. Acesso em 07 de julho de 2015.

VIAN, C. E. F.; ANDRADE JÚNIOR, A. M. Evolução histórica da indústria de máquinas agrícolas no mundo: origens e tendências. $48^{\circ}$ Congresso SOBER Sociedade Brasileira de Economia, Administração e Sociologia Rural - Tecnologia, Desenvolvimento e Integração Social. 2010. Disponível em: http://www.sober.org.br/palestra/15/1208.pdf. Acesso em 29 de outubro de 2013. 